\title{
IMPLEMENTASI TIK DALAM MENINGKATKAN KOMPETENSI GURU PAUD MELALUI KNOWLEDGE MANAGEMENT SYSTEM
}

\author{
IMPLEMENTATION OF ICT IN IMPROVING EARLY CHILDHOUD \\ EDUCATION (ECE) TEACHER COMPETENCE THROUGH \\ KNOWLEDGE MANAGEMENT SYSTEM
}

\author{
Yuni Sugiarti, U. Maman, Suci Ratnawati \\ Fakultas Sains dan Teknologi, UIN Sarif Hidayatullah Jakarta \\ Jalan Ciputat Raya, Ciputat, Tangerang Selatan - Banten. \\ yunianwas@yahoo.co.id
}

diterima: 07 Oktober 2013; dikembalikan untuk direvisi: 21 Oktober 2013; disetujui: 07 November 2013

\begin{abstract}
Abstrak: Tujuan penelitian ini adalah untuk mengetahui penguasaan kompetensi guru PAUD, khususnya kompetensi pedagogik dan kompetensi profesional. Penelitian ini merupakan penelitian pengembangan dalam mengimplementasikan website sistem pembelajaran melalui sharing Knowledge Management System (KMS). Pada penelitian pendahuluan ini diketahui bahwa secara umum penguasaan kompetensi pedagogik dan kompetensi profesional yang dipersyaratkan sebagai guru PAUD masih rendah. Oleh karena itu salah satu pemecahannya adalah mendayagunakan teknologi informasi dan komunikasi khususnya merancang website untuk para guru PAUD sebagai sarana sharing sumber belajar. Sistem tersebut adalah portal pembelajaran guru PAUD melalui sharing komunitas keilmuan (kompetensi pedagogis dan profesional) berbasis web dengan menggunakan PHP Mysql. Melalui sistem ini para guru PAUD dapat berbagi ilmu pengetahuan dan pengalaman antar sesama guru ataupun dengan pihakpihak terkait lainnya. Dengan sistem tersebut juga diharapkan mampu mendorong dan menciptakan para guru untuk lebih kondusif meningkatkan kompetensinya secara mandiri tanpa mengganggu tugas mengajarnya sebagai guru PAUD.
\end{abstract}

Kata kunci: Pendidikan Anak Usia Dini, kompetensi guru PAUD, Knowledge Management System.

\begin{abstract}
The purpose of this study was to determine the competency mastery of early childhood teachers, especially pedagogical competence and professional competence. This research was the development of a system implementing learning through sharing website Knowledge Management System (KMS). In the preliminary study, it is known that in general pedagogical mastery and professional competence required as early childhood teachers is low. Therefore, one solution is to leverage information and communication technologies in particular designing a website for early childhood teachers as a means of sharing learning resources. The system is a learning portal community early childhood teachers through the sharing of knowledge (pedagogical and professional competence) using a web-based PHP Mysql. Through this system, early childhood teachers can share knowledge and experience among fellow teachers or with other relevant parties. With such a system is also expected to encourage and create a more conducive teachers to improve their competence independently without their duty as an early childhood teacher.
\end{abstract}

Keywords : Early Childhood Education, early childhood teacher competence, Knowledge Management System 


\section{Pendahuluan}

Pendidikan hakekatnya dimulai sejak lahir bahkan sejak dalam kandungan ibu hingga akhir hayat. Pendidikan Anak Usia Dini (PAUD) merupakan salah satu tahapan pendidikan anak sejak lahir sampai usia memasuki jenjang pendidikan dasar (Sekolah Dasar), yaitu sekitar usia enam tahun. Umur anak pada masa PAUD dapat digolongkan mulai dari nol tahun hingga enam tahun. Menurut UU No. 20 Tahun 2003 tentang Sistem Pendidikan Nasional dinyatakan bahwa "Pendidikan Anak Usia Dini adalah suatu upaya pembinaan yang ditujukan kepada anak sejak lahir sampai dengan usia enam tahun yang dilakukan melalui pemberian rangsangan pendidikan untuk membantu pertumbuhan dan perkembangan jasmani dan ruhani agar anak memiliki kesiapan dalam memasuki pendidikan lebih lanjut". Sedangkan pada pasal 28 tentang pendidikan anak usia dini dinyatakan bahwa pendidikan anak usia dini diselenggarakan sebelum jenjang pendidikan dasar, dapat diselenggarakan melalui jalur pendidikan formal, nonformal, dan atau informal. Ketentuan tentang Pendidikan Anak Usia Dini tercantum dalam Peraturan Menteri Pendidikan Nasional (Permendiknas) Republik Indonesia Nomor 58 Tahun 2009 tentang Standar Pendidikan Anak Usia Dini (PAUD).

Dalam banyak kajian ilmiah, Pendidikan Anak Usia Dini merupakan bentuk pendidikan yang sangat penting dalam menyiapkan generasi yang berkualitas. Pada masa ini seringkali disebut sebagai masa golden age. Oleh karena itu Pendidikan Anak Usia Dini merupakan salah satu prioritas Kementerian Pendidikan dan Kebudayaan Republik Indonesia.

Pendidikan Anak Usia Dini dilaksanakan oleh pemerintah bersama-sama dengan masyarakat. Bentuk pelaksanaan PAUD meliputi yaitu Taman Kanak-Kanak (TK), Kelompok Bermain (KB), Taman Penitipan Anak (TPA), Taman Pendidikan AI Qur'an (TPQ), dan bentuk Pendidikan Anak Usia Dini lainnya yang berbasis masyarakat, keluarga atau lingkungan. Berdasarkan data dari Kementerian Pendidikan dan Kebudayaan (2011), akses layanan PAUD atau Angka Partisipasi Kasar (APK) anak PAUD hingga akhir tahun 2009 baru mencapai 53,70\% atau sekitar 15,5 juta anak yang terlayani. Keberhasilan angka partisipasi PAUD yang baru mencapai 53,7\% tersebut, ternyata hampir separuhnya $(25,66 \%)$ merupakan kontribusi dari Taman Pendidikan AI Qur'an (TPQ) yang sebetulnya tidak dirancang sebagai satuan PAUD (Kemdikbud, 2011). PAUD model ini dilaksanakan oleh masyarakat. Para guru dan pengelola PAUD berbasis masyarakat ini umumnya belum mendapatkan pendidikan khusus dalam mengajar dan mendidik anak-anak usia PAUD. Kemampuan mereka dalam mendidik anak PAUD umumnya mengandalkan pengalaman empirik dalam mendidik anak-anaknya. Sesungguhnya dalam mendidik anak usia dini lebih rumit karena usia anak tersebut merupakan masa tumbuh kembang yang sangat berpengaruh dalam perkembangan dan kehidupannya di masa mendatang (Sugiarti, 2013).

Dengan pertimbangan pentingnya PAUD sebagai bagian dari pendidikan nasional dan kondisi guru-guru PAUD berbasis masyarakat yang kompentensinya masih terbatas, maka sangat perlu pendayagunaan Teknologi Informasi dan Komunikasi (TIK). Pendayagunaan TIK untuk meningkatkan kompetensi guru, menurut Anwas (2013) dapat dilakukan melalui online, offline, dan berbasis broadcash. Salah satu bentuk TIK yang sesuai dengan kondisi tersebut adalah berbasis online yaitu sistem berbasis web. Untuk mengimplementasikan website sistem pembelajaran dapat dilakukan melalui knowledge management system dalam meningkatkan kompetensi para guru PAUD. Salah satu keunggulan sistem ini para guru bisa lebih aktif meningkatkan kompetensi dan sharing antar sesama guru PAUD dan pihak-pihak terkait lainnya. Diharapkan sistem Portal Pembelajaran Guru PAUD melalui sharing komunitas keilmuan berbasis web dengan menggunakan PHP Mysq/ menjadi media untuk knowledge sharing guruguru PAUD.

Untuk mengimplementasikan website sistem pembelajaran melalui knowledge management system diperlukan kegiatan penelitian pengembangan dalam tiga tahap, yaitu tahap pertama penelitian pendahuluan, tahap kedua pengembangan web Sistem Pembelajaran melalui knowledge management system, dan tahap ketiga uji coba hasil pengembangan web. Tulisan ini fokus terhadap penelitian pendahuluan, yaitu menggali kesulitan apa yang dihadapi para guru PAUD dalam mengembangkan 
Yuni Sugiarti, U. Maman, Suci Ratnawati: Implementasi TIK dalam Meningkatkan Kompetensi Guru PAUD melalui Knowledge Management System

kompetensi, khususnya kompetensi pedagogik dan kompetensi profesional. Oleh karena itu tujuan penelitian ini adalah menggali data dari guru-guru PAUD tentang pemahaman mereka terhadap kompetensi guru khususnya kompetensi pedagogik dan kompetensi profesional. Kedua aspek kompetensi ini dipilih selain alasan penting, juga aspek ini bisa dilakukan treatment untuk ditingkatkan melalui pendayagunaan Teknologi Informasi dan Komunikasi (TIK).

\section{Kajian Literatur}

Sistem Informasi Berbasis Web adalah seperangkat komponen yang saling berhubungan yang berfungsi mengumpulkan, memproses, menyimpan, dan mendistribusikan informasi untuk mendukung pembuatan keputusan dan pengawasan dalam organisasi. Web atau WWW (Word Wide Web) adalah sebuah metode baru yang berjalan di dunia internet yang berkembang dengan cepat, dengan media ini dapat menciptakan puluhan bahkan ratusan aplikasi yang berjalan di bawah Web (under web). PHP adalah salah satu aplikasi program yang biasa digunakan dalam media internet saat ini. Databasenya adalah MySQL yaitu database server yang dapat berjalan di dalam media online sehingga database ini mudah dikelola oleh penggunanya (Nugroho, 2004). MySQL merupakan RDBMS (Relational Data Base Management Sistem). MySQL didistribusikan secara open source dan gratis mulai tahun 1996, tetapi mempunyai sejarah pengembangan sejak tahun 1979.

Knowledge Management atau manajemen pengetahuan pada dasarnya muncul untuk menjawab pertanyaan bagaimana seharusnya mengelola pengetahuan dan bagaimana mengelolanya. Kesadaran untuk menerapkan pendekatan manajemen pengetahuan ke dalam suatu organisasi karena terbukti organisasi yang menjadikan sumber daya pengetahuan sebagai aset utamanya senantiasa mampu mendorong organisasi lebih inovatif yang bermuara kepada kepemilikan daya saing organisasi terhadap para pesaingnya. Tiwana (2000) mendefinisikan knowledge management sebagai pengelolaan pengetahuan secara terorganisasi untuk membuat nilai bisnis dan membangkitkan keuntungan yang bersaing". Menurut Carl Davidson dan Philip Voss (Setiarso, 2009) mengartikan knowledge management adalah bagaimana orang-orang dari berbagai tempat yang berbeda mulai saling bicara. Davidsion dan voss juga mengatakan bahwa sebenarnya mengelola knowledge merupakan cara organisasi mengelola karyawan mereka dan berapa lama mereka menghabiskan waktu untuk menggunakan teknologi informasi.

Sistem web berbasis knowlarge manajemen memberikan peluang berupa sumber belajar kepada para guru khususnya guru PAUD untuk dapat belajar lebih aktif dalam meningkatkan kompetensinya. Melalui sistem ini, guru PAUD juga dapat bertukar pengalaman di antara sesama guru atau dengan pihak-pihak lainnya. Pendidikan anak usia dini merupakan salah satu bentuk penyelenggaraan pendidikan yang menitikberatkan pada peletakan dasar ke arah pertumbuhan dan perkembangan fisik (koordinasi motorik halus dan kasar), kecerdasan (daya pikir, daya cipta, kecerdasan emosi, kecerdasan spiritual), sosio emosional (sikap dan perilaku serta agama) bahasa dan komunikasi, sesuai dengan keunikan dan tahap-tahap perkembangan yang dilalui oleh anak usia dini. (Adalilla, 2010).

Secara umum, tujuan pendidikan anak usia dini adalah mengembangkan berbagai potensi anak sejak dini sebagai persiapan untuk hidup dan dapat menyesuaikan diri dengan lingkungannya. Pendidikan anak pun bisa dimaknai sebagai usaha mengoptimalkan potensi-potensi luar biasa anak yang bisa dibingkai dalam pendidikan, pembinaan terpadu, maupun pendampingan.

Kompetensi mengarahkan individu untuk memiliki kemampuan atau kualifikasi yang disyaratkan dalam melaksanakan tugasnya sehari-hari. Kompetensi prasyarat ini merupakan jaminan individu dalam melaksanakan tugasnya sesuai standarisasi yang telah ditetapkan. Dalam Peraturan Mendiknas Nomor 16 tahun 2007 tentang standar Kualifikasi Akademik dan Kompetensi Guru, telah dijabarkan secara rinci standar kompetensi guru khususnya guru PAUD/TK/RA. Standar kompetensi guru ini dikembangkan secara utuh dari empat kompetensi utama, yaitu kompetensi pedagogik, kompetensi kepribadian, kompetensi sosial, dan kompetensi profesional. Keempat kompetensi tersebut saling terkait dan terintegrasi dalam wujud 
kinerja guru.

Secara lebih rinci dalam Peraturan Mendiknas Nomor 16 tahun 2007 tentang standar Kualifikasi Akademik dan Kompetensi Guru, telah diuraikan penjelasan setiap kompetensi inti guru termasuk kompetensi guru TK/PAUD. Kompetensi tersebut misalnya dalam aspek pedagogik penjelasan dari kompetensi inti guru "Menguasai karakteristik peserta didik dari aspek fisik, moral, sosial, kultural, emosional, dan intelektual", sebagai berikut: 1) Memahami karakteristik peserta didik usia TK/PAUD yang berkaitan dengan aspek fisik, intelektual, sosialemosional, moral, dan latar belakang sosial-budaya; 2) Mengidentifikasi potensi peserta didik usia TK/PAUD dalam berbagai bidang pengembangan; 3) Mengidentifikasi kemampuan awal peserta didik usia TK/PAUD dalam berbagai bidang pengembangan; dan 4) Mengidentifikasi kesulitan peserta didik usia TK/ PAUD dalam berbagai bidang Pengembangan. Begitu pula kompetensi inti guru lainnya pada setiap aspek telah diuraikan lebih spesifik dalam kompetensi guru TK/PAUD. Adanya Peraturan menteri ini dapat menjadi acuan para guru PAUD, pengelola PAUD, dinas pendidikan, lembaga pendidikan tenaga kependidikan, dan pihak-pihak terkait lainnya dalam meningkatkan kompetensi guru PAUD.

\section{Metode Penelitian}

Penelitian ini merupakan penelitian pengembangan yang dilakukan dalam tiga tahap. Tahap pertama adalah penelitian pendahuluan, tahap kedua pengembangan web sistem pembelajaran melalui knowledge management system dalam meningkatkan kompetensi para guru PAUD, dan tahap ketiga uji coba hasil pengembangan web. Pada penelitian pendahuluan ini ditujukan untuk mengumpulkan data tentang kemampuan guru PAUD dalam melaksanakan kompetensi pedagogik dan kompetensi profesional. Populasi dalam penelitian ini adalah guru-guru PAUD yang ada di kecamatan Duren Sawit Jakarta Timur. Sampel diambil secara random sebanyak 89 guru. Pengumpulan data di lapangan dilaksanakan pada bulan Juni tahun 2013. Instrumen pengumpulan data dikembangkan berdasarkan indikator kompetensi guru PAUD pada aspek kompetensi pedagogik dan kompetensi profesional sesuai Peraturan Mendiknas Nomor 16 tahun 2007 tentang standar Kualifikasi Akademik dan Kompetensi Guru. Kompetensi inti guru dalam aspek Pedagogik, meliputi: (a). Menguasai karakteristik peserta didik dari aspek fisik, moral, sosial, kultural, emosional, dan intelektual; (b). Menguasai teori belajar dan prinsip-prinsip pembelajaran yang mendidik; (c). Mengembangkan kurikulum yang terkait dengan bidang pengembangan yang diampu; (d). Menyelenggarakan kegiatan pengembangan yang mendidiK; (e). Memanfaatkan teknologi informasi dan komunikasi untuk kepentingan penyelenggaraan kegiatan pengembangan yang mendidik; (f). Memfasilitasi pengembangan potensi peserta didik untuk mengaktualisasikan berbagai potensi yang dimiliki; (g). Berkomunikasi secara efektif, empatik, dan santun dengan peserta didik; (h). Menyelenggarakan penilaian dan evaluasi proses dan hasil belajar; (i). Memanfaatkan hasil penilaian dan evaluasi untuk kepentingan pembelajaran; (j). Melakukan tindakan reflektif untukpeningkatan kualitas pembelajaran.

Kompetensi inti guru dalam aspek profesional, meliputi: (a). Menguasai materi, struktur, konsep, dan pola pikir keilmuan yang mendukung mata pelajaran yang diampu; (b). Menguasai standar kompetensi dan kompetensi dasar mata pelajaran/bidang pengembangan yang diampu; (c). Mengembangkan materi pembelajaran yang diampu secara kreatif; (d). Mengembangkan keprofesionalan secara berkelanjutan dengan melakukan tindakan reflektif; (e). Memanfaatkan teknologi informasi dan komunikasi untuk berkomunikasi dan mengembangkan diri.

Quesioner yang dikembangkan berdasarkan Permendiknas tersebut, sebelum dilakukan penelitian sebenarnya, dilakukan uji validitas dan reliabilitas. Hasil uji validitas empirik dan uji reliabilitas menunjukkan bahwa questioner tersebut valid dan reliabel, sehingga layak untuk digunakan dalam pengumpulan data. Pengumpulan data juga dilakukan melalui pengamatan dan wawancara terhadap guru PAUD sebagai upaya mengumpulkan data kualitatif dalam menguatkan data yang diperoleh dari questioner. Analisis data menggunakan statistik deskriptif dengan pengolahan data menggunakan bantuan aplikasi SPSS. 
Yuni Sugiarti, U. Maman, Suci Ratnawati: Implementasi TIK dalam Meningkatkan Kompetensi Guru PAUD melalui Knowledge Management System

\section{Hasil dan Pembahasan}

Karakteristik responden dalam penelitian ini adalah sebanyak 89 orang yang terdiri dari: jenis kelamin, tingkat pendidikan formal terakhir, umur, dan pengalaman mengajar yang dihitung dalam satuan tahun. Karakteristik responden seperti digambarkan dalam Tabel 1, keseluruhan hasil penelitian di lapangan 100 persen adalah perempuan. Ini artinya bahwa profesi guru PAUD masih didominasi oleh kaum perempuan.

Tabel 1

Deskripsi Karakteristik Responden

\begin{tabular}{clll}
\hline $\begin{array}{c}\text { Deskripsi } \\
\text { Karakteristik } \\
\text { Responden }\end{array}$ & Katagori & Persentase & Jumlah \\
\hline Jenis Kelamin & Laki-laki & - & - \\
& Perempuan & 89 & 100 \\
Tingkat Pendidikan & SD & 2 & 2.2 \\
& SMP & 3 & 3.4 \\
& SMA & 69 & 77.5 \\
& D2 & 13 & 14.6 \\
& D3 & 2 & 2 \\
\hline Rentang Umur & $25-34$ & 27 & 31.2 \\
& $35-44$ & 39 & 43.1 \\
& $45-54$ & 16 & 17.9 \\
& $55-64$ & 7 & 7.8 \\
\hline Pengalaman & & & \\
Mengajar & 1 & 1 & 1.1 \\
& 2 & 15 & 16.9 \\
& 3 & 16 & 18.0 \\
& 4 & 41 & 46. \\
& 5 & 16 & 18.0 \\
\hline & & &
\end{tabular}

Karakteristik responden dari aspek tingkat pendidikan terakhir, seperti yang dijelaskan dalam Tabel 1, terdiri dari lulusan SD, SMP, SMA, D2, dan D3. Lulusan SD masih ada 2.2 persen, lulusan SMP ada 3.4 persen, Iulusan SMA ada 77.5 persen, Iulusan D2 ada 14.6 persen dan lulusan D3 hanya 2.2 persen. Data ini menunjukkan bahwa profesi guru PAUD sebagian besar masih yang berpendidikan SMA ke bawah. Padahal menurut ketentuan pemerintah, tingkat pendidikan bagi guru yang mengajar di PAUD minimal harus berpendidikan PGTK atau D2 bahkan strata satu. Hal ini masih menjadi pekerjaan rumah bagi lembaga PAUD dan pemerintah untuk meningkatkan kualifikasi guru PAUD minimal setingkat PGTK.

Umur atau usia responden seperti disajikan dalam Tabel 1, sebagian besar (39 persen) berada dalam usia 35 s.d. 44 tahun, dan hanya sekitar tujuh persen usia 55 s.d 64 tahun. Data ini menunjukkan bahwa guru PAUD sebagian besar usianya merupakan usia produktif untuk bekerja. Ini merupakan modal sumber daya manusia (SDM) yang sangat berharga dalam meningkatkan mutu atau kualitas di PAUD tersebut. Pengalaman mengajar responden dijelaskan dalam Tabel 1, sebagian besar berada dalam pengalaman empat tahun yaitu 46 persen; dan hanya sebagain kecil saja (1.1 persen) responden yang hanya memiliki pengalaman mengajar satu tahun. Jika dikaitkan dengan umur responden dalam Tabel 1 di atas, maka pengalaman mengajar ini berkorelasi positif dengan umur responden. Artinya semakin tinggi umur responden maka pengalaman mengajarnya juga semakin lama (berpengalaman).

Secara umum penguasaan kompetensi pedagogik (Tabel 2) guru PAUD sebagian besar masih rendah. Secara lebih khusus kompetensi pedagogik pada aspek pertama yaitu menguasai salah satu karakteristik peserta didik juga rendah. Berdasarkan Tabel 2 diketahui bahwa ternyata ada 14 responden atau $15.7 \%$ guru PAUD yang masih belum menguasai kompetensi aspek ini, hampir setengahnya (48.3\%) atau 43 responden menyatakan kurang menguasai, dan hanya $36 \%$ atau 32 responden yang menyatakan telah menguasai kompetensi ini. Dengan demikian kompetensi guru pada aspek ini masih kurang dikuasai.

Kompetensi Pedagogik sebagai guru PAUD yang kedua adalah menguasai prinsip-prinsip pembelajaran yang mendidik. Berdasarkan Table 2 diketahui bahwa ternyata ada 3 responden atau 3.4\% masih belum menguasai kompetensi aspek ini, lebih dari setengahnya (66.3\%) atau 59 responden menyatakan kurang menguasai, dan hanya $30.3 \%$ atau 27 responden yang menyatakan telah menguasai kompetensi ini. Dengan demikian kompetensi guru pada aspek ini masih kurang dikuasai. 
Tabel 2

Kompetensi Pedagogik dan

Kompetensi Profesional

\begin{tabular}{|c|c|c|c|}
\hline $\begin{array}{l}\text { Jenis } \\
\text { Kompe } \\
\text { tensi }\end{array}$ & Kategori & $\mathbf{f}$ & $\%$ \\
\hline \multirow[t]{10}{*}{ Pedagogik } & $\begin{array}{l}\text { 1. Menguasai salah satu } \\
\text { karakteristik peserta didik }\end{array}$ & $\begin{array}{l}14 \\
43 \\
32\end{array}$ & $\begin{array}{l}15.7 \\
48.3 \\
36.0\end{array}$ \\
\hline & $\begin{array}{l}\text { 2. Menguasai prinsip-prinsip } \\
\text { pembelajaran yang mendidik }\end{array}$ & $\begin{array}{r}3 \\
59 \\
27\end{array}$ & $\begin{array}{r}3.4 \\
66.3 \\
30.3\end{array}$ \\
\hline & $\begin{array}{l}\text { 3. Mengembangkan kurikulum yang } \\
\text { terkait dengan bidang } \\
\text { pengembangan yang di ajarkan } \\
\text { kepada anak didik }\end{array}$ & $\begin{array}{r}5 \\
52 \\
12 \\
20\end{array}$ & $\begin{array}{r}5.65 \\
8.4 \\
13.5 \\
22.5\end{array}$ \\
\hline & $\begin{array}{l}\text { 4. Menyelenggarakan kegiatan } \\
\text { yang mendidik }\end{array}$ & $\begin{array}{r}7 \\
47 \\
20 \\
15 \\
7\end{array}$ & $\begin{array}{r}7.9 \\
52.8 \\
22.5 \\
16.9 \\
7.9\end{array}$ \\
\hline & $\begin{array}{l}\text { 5. Memanfaatkan teknologi informasi } \\
\text { dan komunikasi untuk kepentingan } \\
\text { penyelenggaraan kegiatan } \\
\text { pengembangan yang mendidik }\end{array}$ & $\begin{array}{l}22 \\
37 \\
19 \\
11\end{array}$ & $\begin{array}{l}24.7 \\
41.6 \\
21.3 \\
12.4\end{array}$ \\
\hline & $\begin{array}{l}\text { 6. Memfasilitasi pengembangan } \\
\text { potensi peserta didik untuk } \\
\text { mengaktualisasikan berbagai } \\
\text { potensi yang dimiliki }\end{array}$ & $\begin{array}{r}8 \\
42 \\
32 \\
7\end{array}$ & $\begin{array}{r}9.0 \\
47.2 \\
36.0 \\
7.9\end{array}$ \\
\hline & 7. Berkomunikasi secara efektif & $\begin{array}{r}6 \\
40 \\
43\end{array}$ & $\begin{array}{r}6.74 \\
4.9 \\
48.3\end{array}$ \\
\hline & $\begin{array}{l}\text { 8. Melakukan penilaian dan } \\
\text { evaluasi proses dan hasil belajar }\end{array}$ & $\begin{array}{l}21 \\
34 \\
34 \\
21\end{array}$ & $\begin{array}{l}23.6 \\
38.2 \\
38.2 \\
23.6\end{array}$ \\
\hline & $\begin{array}{l}\text { 9. Memanfaatkan hasil penilaian dan } \\
\text { evaluasi untuk kepentingan } \\
\text { pembelajaran }\end{array}$ & $\begin{array}{r}8 \\
41 \\
10 \\
30\end{array}$ & $\begin{array}{r}9.0 \\
46.1 \\
11.2 \\
33.7\end{array}$ \\
\hline & $\begin{array}{l}\text { 10. Tindakan reflektif untuk } \\
\text { peningkatan kualitas pembelajaran }\end{array}$ & $\begin{array}{r}6 \\
26 \\
52 \\
5\end{array}$ & $\begin{array}{r}6.7 \\
29.2 \\
58.4 \\
5.6\end{array}$ \\
\hline \multirow[t]{5}{*}{ Profesional } & $\begin{array}{l}\text { 1. Menguasai materi yang mendukung } \\
\text { mata pelajaran yang diampu }\end{array}$ & $\begin{array}{r}99 \\
42 \\
26 \\
12\end{array}$ & $\begin{array}{l}10.1 \\
47.2 \\
29.2 \\
13.5\end{array}$ \\
\hline & $\begin{array}{l}\text { 2. Menguasai kompetensi dasar mata } \\
\text { pelajaran/bidang } \\
\text { pengembangan yang diampu. }\end{array}$ & $\begin{array}{r}9 \\
46 \\
33 \\
1\end{array}$ & $\begin{array}{r}10.1 \\
51.7 \\
37.1 \\
1.1\end{array}$ \\
\hline & $\begin{array}{l}\text { 3. Mengembangkan materi } \\
\text { pembelajaran yang diampu } \\
\text { secara kreatif }\end{array}$ & $\begin{array}{r}4 \\
54 \\
21 \\
10 \\
4\end{array}$ & $\begin{array}{r}4.5 \\
60.7 \\
23.6 \\
11.2 \\
4.5\end{array}$ \\
\hline & $\begin{array}{l}\text { 4. Mengembangkan keprofesionalan } \\
\text { secara berkelanjutan }\end{array}$ & $\begin{array}{l}22 \\
47 \\
20 \\
22\end{array}$ & $\begin{array}{l}24.7 \\
52.8 \\
22.5 \\
24.7\end{array}$ \\
\hline & $\begin{array}{l}\text { 5. Memanfaatkan teknologi } \\
\text { informasi dan komunikasi untuk } \\
\text { berkomunikasi dan } \\
\text { mengembangkan diri }\end{array}$ & $\begin{array}{r}11 \\
53 \\
20 \\
5\end{array}$ & $\begin{array}{r}12.4 \\
59.6 \\
22.5 \\
5.6\end{array}$ \\
\hline
\end{tabular}

Kompetensi Pedagogik sebagai guru PAUD yang ketiga adalah mengembangkan kurikulum yang terkait dengan bidang pengembangan yang diajarkan kepada anak didik. Berdasarkan Tabel 2 diketahui bahwa ternyata ada 5 responden atau $5.6 \%$ tidak pernah mengembangkan kompetensi aspek ini, lebih dari setengahnya (58.4\%) atau 52 responden menyatakan pernah satu atau dua kali mengembangkan kompetensi aspek ini, $13.5 \%$ atau 12 responden yang menyatakan jarang mengembangkan kompetensi aspek ini, dan hanya $22.5 \%$ atau 20 responden guru yang telah mengembangkan kompetensi aspek ini. Dengan demikian kompetensi guru pada aspek ini juga masih kurang dikuasai guru PAUD.

Kompetensi Pedagogik sebagai guru PAUD yang keempat adalah menyelenggarakan kegiatan yang mendidik. Berdasarkan Table 2 diketahui bahwa ternyata hanya ada 7 responden atau $7.9 \%$ tidak pernah menyelenggarakan kompetensi aspek ini, lebih dari setengahnya (52.8\%) atau 47 responden menyatakan pernah satu atau dua kali, $22.5 \%$ atau 20 responden guru jarang menyelenggarakan kompetensi aspek ini dan hanya $16.9 \%$ atau 15 responden yang menyatakan sering menyelenggarakan kompetensi aspek ini. Dengan demikian kompetensi guru pada aspek ini masih kurang.

Kompetensi Pedagogik sebagai guru PAUD yang kelima adalah memanfaatkan teknologi informasi dan komunikasi untuk kepentingan penyelenggaraan kegiatan pengembangan yang mendidik. Berdasarkan Tabel 2 diketahui bahwa ternyata ada 22 responden atau $24.7 \%$ menyatakan tidak pernah memanfaatkan kompetensi aspek ini, Sebanyak $41.6 \%$ atau 37 responden menyatakan pernah satu atau dua kali, $21.3 \%$ atau 19 responden guru jarang memanfaatkan kompetensi aspek ini dan hanya $21.3 \%$ atau 11 responden yang menyatakan sering memanfaatkan kompetensi aspek ini. Dengan demikian kompetensi guru pada aspek ini masih kurang.

Kompetensi Pedagogik sebagai guru PAUD yang keenam adalah memfasilitasi pengembangan potensi peserta didik untuk mengaktualisasikan berbagai potensi yang dimiliki. Berdasarkan Tabel 2 diketahui bahwa ternyata ada 8 responden atau 9.0\% menyatakan tidak pernah memfasilitasi kompetensi 
Yuni Sugiarti, U. Maman, Suci Ratnawati: Implementasi TIK dalam Meningkatkan Kompetensi Guru PAUD melalui Knowledge Management System

aspek ini, Sebanyak $47.2 \%$ atau 42 responden menyatakan pernah satu atau dua kali, $36.0 \%$ atau 32 responden guru jarang memfasilitasi kompetensi aspek ini dan hanya $7.9 \%$ atau 7 responden yang menyatakan sering memfasilitasi pengembangan potensi peserta didik untuk mengaktualisasikan berbagai potensi yang dimiliki. Dengan demikian kompetensi guru pada aspek ini masih kurang.

Kompetensi Pedagogik sebagai guru PAUD yang ketujuh adalah berkomunikasi secara efektif dengan peserta didik. Berdasarkan Tabel 2 diketahui bahwa ternyata ada 6 responden atau $6.7 .0 \%$ menyatakan kurang, Sebanyak $44.9 \%$ atau 40 responden menyatakan cukup, dan hanya $48.3 \%$ atau 43 responden yang menyatakan iya berkomunikasi secara efektif, empatik, dan santun dengan peserta didik. Dengan demikian kompetensi guru pada aspek ini bisa dikatakan cukup dikuasai guru PAUD.

Kompetensi Pedagogik sebagai guru PAUD yang kedelapan adalah melakukan penilaian dan evaluasi proses dan hasil belajar. Berdasarkan Tabel 2 diketahui bahwa ternyata ada 21 responden atau $23.6 \%$ menyatakan kurang, Sebanyak $38.2 \%$ atau 34 responden menyatakan kadang-kadang, dan dengan jumlah yang sama (38.2\%) atau 34 responden menyatakan selalu melakukan penilaian dan evaluasi proses dan hasil belajar. Dengan demikian kompetensi guru pada aspek ini sudah bagus dikuasai oleh guru PAUD.

Kompetensi Pedagogik sebagai guru PAUD yang kesembilan adalah memanfaatkan hasil penilaian dan evaluasi untuk kepentingan pembelajaran. Berdasarkan Table 2 ketahui bahwa ternyata ada 8 responden atau $9 \%$ menyatakan tidak pernah, Sebanyak $46.1 \%$ atau 41 responden menyatakan kadang-kadang, Ada $11.2 \%$ atau 10 responden menyatakan sering, dan (33.7\%) atau 30 responden menyatakan selalu memanfaatkan hasil penilaian dan evaluasi untuk kepentingan pembelajaran. Dengan demikian kompetensi guru pada aspek ini bisa dikatakan cukup.

Kompetensi Pedagogik sebagai guru PAUD yang kesepuluh adalah melakukan tindakan reflektif untuk peningkatan kualitas pembelajaran. Berdasarkan Tabel 2 di atas diketahui bahwa ternyata ada 6 responden atau $6.7 \%$ menyatakan tidak pernah, Sebanyak (29.2\%) atau 26 responden menyatakan kadangkadang, Ada (58.4\%) atau 52 responden menyatakan sering, dan (5.6\%) atau 5 responden menyatakan selalu melakukan tindakan reflektif untuk peningkatan kualitas pembelajaran. Dengan demikian kompetensi guru pada aspek ini bisa dikatakan cukup.

Secara umum kompetensi profesional sebagai guru PAUD juga masih rendah. Kompetensi profesional sebagai guru PAUD yang kesatu adalah menguasai materi keilmuan yang mendukung mata pelajaran yang diampu. Berdasarkan Tabel 2 di atas diketahui bahwa ternyata ada 9 responden atau $10.1 \%$ menyatakan tidak pernah, Sebanyak $47.2 \%$ atau 42 responden menyatakan kadang-kadang, Ada (29.2\%) atau 26 responden menyatakan sering, dan (13.5\%) atau 12 responden menyatakan selalu menguasai materi keilmuan yang mendukung mata pelajaran yang diampu. Dengan demikian kompetensi guru pada aspek ini bisa dikatakan kurang.

Kompetensi Profesional sebagai guru PAUD yang kedua adalah menguasai standar kompetensi dan kompetensi dasar mata pelajaran/ bidang pengembangan yang diampu. Berdasarkan Tabel 2 diketahui bahwa ternyata ada 9 responden atau 10.1\% menyatakan tidak pernah, Sebanyak $51.7 \%$ atau 46 responden menyatakan kadang-kadang, Ada 37.1 atau 33 responden menyatakan sering, dan hanya (1.1\%) atau 1 responden menyatakan selalu menguasai standar kompetensi dan kompetensi dasar mata pelajaran/bidang pengembangan yang diampu. Dengan demikian kompetensi guru pada aspek ini bisa dikatakan kurang.

Kompetensi Profesional sebagai guru PAUD yang ketiga adalah mengembangkan materi pembelajaran yang diampu secara kreatif. Berdasarkan Tabel 2 diketahui bahwa ternyata ada 4 responden atau $4.5 \%$ menyatakan tidak pernah, Sebanyak $60.7 \%$ atau 54 responden menyatakan kadang-kadang, Ada 23.6\% atau 21 responden menyatakan sering, dan $11.2 \%$ atau 10 responden menyatakan selalu mengembangkan materi pembelajaran yang diampu secara kreatif. Dengan demikian kompetensi guru pada aspek ini bisa dikatakan cukup. 
Kompetensi Profesional sebagai guru PAUD yang keempat adalah mengembangkan keprofesionalan secara berkelanjutan dengan melakukan tindakan reflektif. Berdasarkan Table 2 diketahui bahwa ternyata ada 22 responden atau $24.7 \%$ menyatakan tidak pernah, Sebanyak $52.8 \%$ atau 47 responden menyatakan kadang-kadang, dan $22.5 \%$ atau 20 responden menyatakan sering mengembangkan keprofesionalan secara berkelanjutan dengan melakukan tindakan reflektif. Dengan demikian kompetensi guru pada aspek ini bisa dikatakan cukup. Kompetensi Profesional sebagai guru PAUD yang kelima adalah memanfaatkan teknologi informasi dan komunikasi untuk berkomunikasi dan mengembangkan diri. Berdasarkan Tabel 2 diketahui bahwa ternyata ada 11 responden atau $12.4 \%$ menyatakan tidak pernah, Sebanyak (59.6\%) atau 53 responden menyatakan kadang-kadang, dan $22.5 \%$ atau 20 responden menyatakan sering, dan hanya 5 responden (5.6\%) yang menyatakan selalu memanfaatkan teknologi informasi dan komunikasi untuk berkomunikasi dan mengembangkan diri. Dengan demikian kompetensi guru pada aspek ini bisa dikatakan kurang.

Secara umum rendahnya kompetensi pedagogik dan kompetensi profesional yang dikuasai oleh guru PAUD berkorelasi dengan tingkat pendidikan yang sebagian besar masih lulusan SLTA (Tabel 1), bahkan ada yang masih lulusan SD dan SMP. Kondisi ini mendorong semua pihak khususunya pemerintah (Dinas pendidikan terkait) untuk berupaya meningkatkan kualifikasi guru PAUD. Namun upaya konvensional ini memerlukan waktu dan biaya yang relatif besar. Di sisi lain perlu segera diupayakan peningkatan kompetensi di luar pendidikan formal, yaitu dengan memanfaatkan Teknologi Informasi dan Komunikasi (TIK). Oleh karena itu perlu segera merancang website untuk para guru PAUD sebagai sarana sharing sumber belajar. Sistem tersebut adalah portal pembelajaran guru PAUD melalui sharing komunitas keilmuan (kompetensi pedagogis dan profesional) berbasis web dengan menggunakan PHP Mysql selanjutnya menjadi media untuk knowledge sharing guru-guru PAUD.
Hasil pengamatan di lapangan, bahwa di lokasi penelitian yang berada di kota Jakarta, jaringan internet sangat mendukung. Begitu pula guru-guru PAUD di temukan sudah terbiasa menggunakan telpon genggam, internet (chatting, jejaring sosial, email). Namun penggunaan teknologi tersebut masih sekedar untuk kepentingan hiburan dan komunikasi saja. Fasilitas ini perlu didorong untuk digunakan untuk pendidikan terPermasalahanya bagaimana mengubah budaya guru-guru PAUD dari semula pemanfaatan TIK hanya untuk komunikasi dan hiburan saja di ubah menjadi pemanfaatan TIK untuk mendukung peningkatan kompetensinya. Di sinilah salah satu saran dari penelitian ini, perlunya Guru-utama meningkatkan kompetensinya sebagai guru PAUD sesuai tuntutan peserta didik. Oleh karena itu pengembangan web site berbasis knowlarge manajement system diharapkan mampu mendorong dan menciptakan para guru untuk lebih kondusif meningkatkan kompetensinya secara mandiri tanpa menggagu tugasnya mengajar seharihari sebagai guru PAUD.

Sesuai dengan hasil data dari lapangan seperti disajikan dalam analisis deskriptif di atas, maka setiap kegiatan yang ada di PAUD dapat dibuat dan dirumuskan knowledge management system berbasis web dengan proses-proses seperti dalam tabel 3 .

Tabel 3 menunjukkan bahwa sosialisasi adalah proses untuk mendapatkan knowledge baru yang bersifat tacit dari knowledge tacit yang sudah ada. Dalam knowledge management system berbasis web, proses sosialisasi ada dalam fasilitas knowledge capturing. Eksternalisasi, merupakan proses mengubah knowledge yang bersifat tacit menjadi knowledge yang bersifat explicit. Dalam knowledge management system berbasis web proses eksternalisasi ada dalam fasilitas knowledge capturing yaitu pada proses simpan knowledge dimana knowledge yang disimpan ada pengelompokan kategori yaitu pedagogis dan profesional. Kombinasi adalah proses untuk mendapatkan knowledge baru yang bersifat explicit dari knowledge explicit yang sudah ada. Dalam knowledge management system berbasis web, proses kombinasi ada dalam fasilitas knowledge sharing yaitu pada proses mencari knowledge yang di sharing dan pada saat melihat dan mempelajari 
Yuni Sugiarti, U. Maman, Suci Ratnawati: Implementasi TIK dalam Meningkatkan Kompetensi Guru PAUD melalui Knowledge Management System

knowledge. Internalisasi adalah proses mengubah knowledge yang bersifat explicit menjadi knowledge yang bersifat tacit. Dalam knowledge management system berbasis web proses internalisasi ada dalam fasilitas knowledge sharing pada proses memberikan komentar pada knowledge yang sedang dilihat. Hasil analisis tersebut merupakan bahan dalam pengembangan sistem web berbasis Knowledge Management System dalam sistem pembelajaran untuk Pendidikan Anak Usia Dini (PAUD).

Tabel 3 : Analisis Skenario Sistem Kegiatan PAUD

\begin{tabular}{lll}
\hline No. Kegiatan & Pelaksanaan & Proses KM \\
\hline 1. Mengelola data guru & $\begin{array}{l}\text { a. Diskusi } \\
\text { b. Sharing dokumen }\end{array}$ & $\begin{array}{l}\text { a.Sosialisasi } \\
\text { b. Kombinasi } \\
\text { c. Internalisasi }\end{array}$ \\
\hline 2. Melakukan kegiatan belajar mengajar & a.Diskusi & a.Sosialisasi \\
& b.Sharing dokumen & b.Eksternalisasi \\
& c.Knowledge sharing & c.Kombinasi \\
& & d.Internalisasi \\
\hline 3. Menyusun materi pelajaran PAUD & a.Diskusi & a.Sosialisasi \\
& b.Sharing dokumen & b.Eksternalisasi \\
& c.Knowledge sharing & c.Kombinasi \\
& & d.Internalisasi \\
\hline
\end{tabular}

\section{Simpulan dan Saran Simpulan}

Karakteristik responden sebagai guru PAUD didominasi oleh kaum perempuan, dengan tingkat pendidikan sebagian besar lulusan SMA, dan secara usia sebagian besar dalam usia produktif untuk bekerja, serta sebagian besar berpengalaman mengajar selama sekitar empat tahun.

Secara umum penguasaan kompetensi pedagogik sebagia guru PAUD masih rendah. Secara lebih khusus kompetensi pedagogik pada aspek: menguasai salah satu karakteristik peserta didik, menguasai prinsipprinsip pembelajaran yang mendidik, mengembangkan kurikulum yang terkait dengan bidang pengembangan yang diajarkan kepada anak didik, menyelenggarakan kegiatan yang mendidik, memanfaatkan teknologi informasi dan komunikasi untuk kepentingan penyelenggaraan kegiatan pengembangan yang mendidik, dan aspek memfasilitasi pengembangan potensi peserta didik untuk mengaktualisasikan berbagai potensi yang dimiliki masih rendah. Kompetensi Pedagogik pada aspek: berkomunikasi secara efektif dengan peserta didik, memanfaatkan hasil penilaian dan evaluasi untuk kepentingan pembelajaran, dan melakukan tindakan reflektif untuk peningkatan kualitas pembelajaran dalam katagori cukup dikuasai oleh guru PAUD. Sementara itu hanya aspek melakukan penilaian dan evaluasi proses dan hasil belajar yang sudah dikuasai dengan baik oleh guru PAUD dalam kompetensi pedagogik tersebut. Secara umum kompetensi profesional sebagai guru PAUD juga masih rendah. Secara lebih khusus kompetensi profesional sebagai guru PAUD pada aspek: menguasai materi yang mendukung mata pelajaran yang diampu, menguasai standar kompetensi dan kompetensi dasar mata pelajaran/ bidang pengembangan yang diampu, serta aspek memanfaatkan teknologi informasi dan komunikasi untuk berkomunikasi dan mengembangkan diri masih kurang. Dua aspek kompetensi profesional sebagai guru PAUD yaitu aspek: mengembangkan materi pembelajaran yang diampu secara kreatif, mengembangkan keprofesionalan secara berkelanjutan dengan melakukan tindakan reflektif dalam katagori cukup dikuasai oleh guru PAUD.

\section{Saran}

Untuk meningkatkan kompetensi guru PAUD terutama dalam kompetensi pedagogik dan kompetensi profesional perlu dilakukan peningkatan kualifikasi guru PAUD minimal setingkat diploma dua bahkan hingga 
tingkat sarjana. Namun upaya konvensional ini memerlukan waktu dan biaya yang relatif besar. Oleh karena itu salah satu pemecahannya adalah dengan mendayagunakan Teknologi Informasi dan Komunikasi khususnya merancang website untuk para guru PAUD sebagai sarana sharing sumber belajar. Sistem tersebut adalah portal pembelajaran guru PAUD melalui sharing komunitas keilmuan (kompetensi pedagogis dan profesional) berbasis web dengan menggunakan PHP Mysql selanjutnya menjadi media untuk knowledge sharing guru-guru PAUD.

I nfrastruktur Internet di tempat penelitian sangat mendukung (jaringan internet) sangat banyak. Guruguru PAUD di temukan sudah terbiasa menggunakan telpon genggam, internet (chatting, jejaring sosial, email). Permasalahanya bagaimana mengubah budaya guru-guru PAUD dari semula pemanfaatan TIK hanya untuk komunikasi dan hiburan saja di ubah menjadi pemanfaatan TIK untuk mendukung peningkatan kompetensinya. Di sinilah salah satu saran dari penelitian ini, perlunya Guru-guru PAUD untuk membudayakan memanfaatkan web ini sebagai sumber belajar dengan di akses melalui berbagai produk teknologi informasi dan komunikasi untuk keperluan pendidikan. Oleh karena itu pengembangan web site berbasis knowlarge manajement system diharapkan mampu mendorong dan menciptakan para guru untuk lebih kondusif meningkatkan kompetensinya secara mandiri tanpa menggagu tugasnya mengajar seharihari sebagai guru PAUD.

\section{Pustaka Acuan}

Adallila, S. 2010. Pentingnya Pendidikan Anak Usia Dini. http://sadidadallila.wordpress.com (5 Juni 2013)

Anwas, Oos M. 2013. Peran Teknologi Informasi dan Komunikasi dalam Implementasi Kurikulum 2013. Jurnal Teknodik, Vol. 17 No. 1, Maret 2013, Jakarta: Pustekkom Kemdikbud.

Jogiyanto HM. 2008. Analisis dan Desain Sistem Informasi. Pendekatan Terstruktur Teori dan Praktek Aplikasi

Bisnis. Yogyakarta : Andi.

Jogiyanto HM. 2011. Analisa Desain Sistem Informasi : Pendekatan Terstruktur Teori dan PraktekAplikasi Bisnis, Edisi Ketiga, Cetakan Kedua, Yogyakarta: Andi.

Kementerian Pendidikan dan Kebudayaan. 2007. Peraturan Mendiknas Nomor 16 tahun 2007 tentang standar Kualifikasi Akademik dan Kompetensi Guru.

Kementerian Pendidikan dan Kebudayaan. 2008. Peraturan Menteri Pendidikan Nasional No. 38/2008 tentang Pengelolaan TIK di Lingkungan Depdiknas

Kementerian Pendidikan dan Kebudayaan. 2011. Grand Desain Pembangunan PAUD Indonesia Periode 20112025. Jakarta: Direktorat Jenderal Pendidikan Anak Usia Dini, Non Formal dan Informal.

Kendall dan Kendall. 2003. Analisis dan Perancangan Sistem. Jilid 1. Jakarta : PT. Prenhallindo.

Kendall, J. 2008. System Analysis and Design. Seventh Edition. New Jersey : Pearson International Edition.

Pita Larasati, 2010. Memodelkan KMS untuk sharing data informasi, pengetahuan serta komunikasi pada lembaga BPPT. Jurnal IImu Komputer Universitas Indonesia.

Peraturan Menteri Pendidikan Nasional (Permendiknas) Republik Indonesia Nomor 58 Tahun 2009 tentang Standar Pendidikan Anak Usia Dini (PAUD).

Peraturan Mendiknas Nomor 16 tahun 2007.

Sangkala, 2007. Knowledge Management. PT. King Grafindo: Jakarta

Tiwana, Amrit. 2000, The Essential Guide to Knowledge Management: E-Business and CRM Applications

Harjanto Setiarso B, Triyono, Subagyo H. 2009. Penerapan Knowledge Management Pada organisasi. Graha Ilmu:Yogyakarta

Setiarso, Harjanto, Triyono, Subagyo H. 2009. Penerapan Knowledge Management Pada organisasi. Graha Ilmu:Yogyakarta.

Sugiarti, Yuni. 2013. Pendayagunaan Teknologi Informasi dan Komunikasi dalam Meningkatkan Kompetensi Guru Pendidikan Anak Usia Dini (PAUD). Jurnal Teknodik Vol.XVI No 1 Maret 2012. 